\title{
FEEDING STRATEGY FOR IMPROVING DAIRY CATTLE PRODUCTIVITY IN SMALL HOLDER FARM IN BANGLADESH
}

\author{
M. J. Khan ${ }^{1}$, K. J. Peters ${ }^{2}$ and M. M. Uddin ${ }^{2}$
}

\begin{abstract}
Dairy animal rearing is an inseparable and integrated part of smallholder subsistence farming system. Dairy cattle production in the country is characterized by low productivity levels due mainly to genetic and nutritional constraints. Unless feeding management is improved these animals may be limited to fully express their potential genetic superiority. It is fundamental approach to provide good quality diets to dairy cattle in sufficient amount to maximize production. Dairying provides women with a regular daily income vital to household good security and family well being. Quantitative and qualitative shortage of feeds and fodder affects the performance of milking animal. Local cows yield on average 1.5 Lit. milk per day against 5-8 Lit. in cross bred cows, require better feeding mainly concentrates, which is not available to the farmers at the affordable prices. But income of farmers can be increased up to two fold (Tk.58 vs 115) by rearing cross bred cows. Since feed cost is becoming the most important factor in livestock production, increasing self sufficiency in feed production will be an important factor in future development programs.
\end{abstract}

Key words: Small holding farmers, Dairy animals, Feeds, Feeding system

\section{Introduction}

Cattle are an inseparable and integrated part of small holder subsistence farming system. Over ninety per cent of 23.76 million (Agricultural Census, 1996) cattle of the country are indigenous zebu type and the remaining 10 per cent are exotic pure breeds (Shahiwal, Sindhi, Holstein Friesian and Jersey) and their crosses with indigenous. Domestic milk production from these animals accounts only 14 per cent of the total requirement (DLS, 2007), which furnishes approximately $40 \mathrm{ml}$ milk per person per day against the requirement of $250 \mathrm{ml}$. Dairy cattle production in the country is characterized by low productivity levels due mainly to genetic and nutritional constraints. Small holder mixed crop livestock system continue to be a dominant agricultural production system in Bangladesh. Dairy farming is a part and parcel of many such systems, and it is often seem as an important livelihood option to increase households income of mixed farms in Bangladesh.

The classical approach in increase dairy production is through genetic means by crossing with improved breeds. Unless feeding management is improved, these animals

\footnotetext{
${ }_{2}^{1}$ Department of Animal Nutrition, Bangladesh Agricultural University, Mymensingh-2202, Bangladesh

${ }^{2}$ Institute of Animal Sciences, Humboldt-University Berlin, Germany
}

(Received: November 16, 2009) 
may be limited to fully express their potential genetic superiority. It is fundamental approach to provide good quality diets to dairy cattle in sufficient amounts to maximize production. But in the country there is heavy shortage of feed both in quantity and quality.

The traditional feeding system for dairy cattle is based on the use of rice straw, natural grasses supplemented with a little or no concentrates. The quantity and quality of fodder available from natural pasture shows seasonal fluctuation. There is an acute shortage of feed supply during the dry season and the available feed during this period is of very poor quality. Poor nutrition results in low production and reproductive performance slow growth rate, loss of body condition and increased susceptibility to diseases and parasites. Thus, effective utilization of the available feed resources (agricultural and agro-industrial byproducts, natural pastures and browse) and appropriate supplementation of poor quality natural pasture and crop residue based diets appear to be the necessary steps to alleviate the nutritional problems of dairy animals. Different supplementation strategies could be applied depending upon the type, accessibility and price of supplementary feeds in a given area. Fodder conservation practices particularly hay and silage making should be developed in order to enable a stable of feed throughout the year. Evaluation of the nutritive value of naturally occurring tree leaves and pods, which are commonly used as dry season feed resources, would be important to enhance their proper utilization. In view of this situation, research should be directed towards the development of alternate feeding system which make better use of local resource that are available throughout the year.

\section{Existing dairy production system}

Dairy animal rearing is a component of farming system in Bangladesh since ancient time. The animal are reared by farmers for milk production and the cow gives birth female calf is used as future milking animal and male calf is used as future bullock for traction, transport and to sale for cash money. Small farmers keep 1-2 milch animals of low genetic production potential. Most of the dairy farms are small holders and are located in different regions of the country with more concentration to north-west of the country. The average family size of the smallholder dairy farms consists of 5-6 persons, where the adult male and female take cares the animals on a part time work in addition to their normal work. In some areas, farmers have built up groups or cooperatives under the brand name of Milk Vita. The cooperatives gives veterinary and A.I. services free of cost and sell concentrated feed to the members on credit. The farms sell their produced milk to the cooperatives at a fixed price on the basis of milk fat percentage. Their debt and credit is cleared every fortnight. With the above system in operation the farmers produce 1.62 million tonnes milk per day (Saha and Haque, 2001). This amount of milk production can cover only 15 per cent of the requirement. In the last few years milk consumption has increased rapidly and linearly with an estimated $1.2 \%$ increase annually (DLS, 2007).

Paddy and wheat are the most important cereal crops grown in the country, which occupies $80 \%$ of the total cropped area and by- products are fed to the dairy animals. 
Rice straw is the main roughage for dairy cows, which is low in nutritive value and palatability but it contributes $90 \%$ of the roughage feed to animals. The amount of green fodder fed to the cattle each day depends on the time given by the farmers to collect the grass or weeds from roadsides, agricultural land or weeds harvested from the crop fields, rather than the requirement of the cattle. Most of the time of the year, the cattle did not get adequate feed. In the rainy season lush green grass grows in the roadside, embankment and fellow lands, but the farmers can not preserve the surplus green grass because of lack of knowledge, labour and infrastructure. It is left in the field and gets too old, consequently low in quality where the dry matter digestibility becomes lower than $50 \%$ and available nutrients do not reach the minimum requirement level of the cow. Dairy farmer are recommended to feed $1 \mathrm{~kg}$ concentrate for 2-3 $\mathrm{kg}$ of milk yield. Generally, the concentrate feed contain rice polish, wheat bran and oil cakes. Farmers who have low milk production could not afford to buy required amount of concentrate. Under these circumstances, malnutrition induces problems of decreasing milk production and low conception rate. Some farmers maintain 2-3 cross bred cows (crossing local with pure Holstein Friesian and Jersey through A. I.) with milk production 4-6 folds higher than local cattle. These groups of farmers fed concentrate regularly to their animals and grow fodder crops in limited amounts. On the other hand, due to shortage of knowledge some rich farmers fed their cows concentrate adlibitum basis, which makes the animals fatty leads to lower conception rate. The main component of the operating cost of dairy farming is the feed cost. Some available technologies have been applied and demonstrated to farmers at the farm level but the farmers are reluctant to utilize the technologies due to time consuming and botheration of the process.

\section{Feeding practices and input-output levels for local vs crossbred cow}

The major differences between feeding practices of two types of animals local vs crossbred are intake of green fodders and concentrates. The cross bred cows are usually stall fed while the local cows are generally sent out for grazing the whole day and fed rice straw ad libitum basis. The grass offered to the crossbred cows composed of roadside grass, own production fodder, weeds of crop fields, aquatic weeds, tree leaves and other browse which varies from season to season. Local cows are fed to a maximum limit of $1 \mathrm{~kg}$ concentrate daily, usually rice polish of farmer's own source. The crossbred cows are supplied with concentrate in amount 2-3 times higher than local cows and composed of rice polish, wheat bran, brans of legumes and oil cakes.

Input out-put levels of rearing two types of dairy cows can be seen in Table 1. The income through dairying was calculated taking into account the feed cost and price incurred from daily milk yield. In case of local cows, the overall incomes of farmers are far below the income in comparison with cross bred cows. In both type of cows maximum milk yield and profit was found in rainy season and low milk yield at the same time low profit was noticed in summer season of the year. 
Bang. J. Anim. Sci. 2009, 38(1\&2)

Table 1. Daily input and output from rearing two types of dairy cows

\begin{tabular}{|c|c|c|c|c|c|c|c|c|}
\hline \multirow{2}{*}{$\begin{array}{l}\text { Animal category } \\
\text { and season }\end{array}$} & \multirow{2}{*}{ Legend } & \multirow{2}{*}{$\begin{array}{c}\text { Green } \\
\text { fodder } \\
(\mathbf{k g})\end{array}$} & \multirow{2}{*}{$\begin{array}{c}\text { Rice } \\
\text { straw } \\
\text { (kg) }\end{array}$} & \multirow{2}{*}{$\begin{array}{c}\text { Concentrates } \\
(\mathrm{kg})\end{array}$} & \multirow{2}{*}{$\begin{array}{c}\text { Milk yield } \\
\text { (Litre) }\end{array}$} & \multicolumn{3}{|c|}{ Cost benefit (BDT) $^{@}$} \\
\hline & & & & & & Feed & Milk & Profit \\
\hline \multirow[t]{2}{*}{ Feb-May (Dry) } & $\mathrm{a}$ & 1.50 & 7.50 & 1.00 & 1.25 & 30.78 & 31.25 & +0.57 \\
\hline & $b$ & 5.00 & 7.25 & 2.50 & 4.25 & 54.50 & 112.50 & +58.00 \\
\hline \multirow{2}{*}{$\begin{array}{l}\text { June-Septem } \\
\text { (Monsoon) }\end{array}$} & a & 8.47 & 6.53 & 1.00 & 2.15 & 32.28 & 53. & +21.50 \\
\hline & $\mathrm{b}$ & 12.35 & 8.26 & 2.30 & 6.50 & 44.18 & 162.50 & +115.30 \\
\hline \multirow[t]{2}{*}{ Oct-Jan (Winter) } & a & 3.12 & 7.00 & 1.00 & 1.35 & 30.56 & 33.75 & +3.19 \\
\hline & $\mathrm{b}$ & 10.24 & 8.50 & 2.50 & 6.00 & 49.62 & 150.00 & +100.38 \\
\hline
\end{tabular}

${ }^{\mathrm{a}}$ Local cows, ${ }^{\mathrm{b}}$ Crossbred cows

Source: Data are generated from 300 households of 60 northern districts under SLDP-II

${ }^{\circledR}$ Calculations are made considering the price of green fodder 0.50BDT/kg, Rice straw $2.00 \mathrm{BDT} / \mathrm{kg}$, Concentrate 15BDT/kg and milk 25 BDT/ litre

\section{Constraints on raw milk production}

Feeding is recognised as one of the major constraints in livestock production accounts for a large proportion of the cost of milk production (Singh et al., 1993). Quantitative and qualitative shortage of feed and fodder affects the performance of milking animals, through both under and over feeding occurs and this affects of economies of milk production negatively. Feed shortage in the dry season is the most serious problem of the small dairy producers. Rice straw is the only roughage during this period. On the other hand, urea treated straw is not widely practised by the farmers. Utilization of other crop residues such as sugarcane top is also not well adopted. High cost of concentrate feed, which goes up day by day becomes out of buying capacity of the farmers is an acute problem in rearing milking animal. Another constraint is shortage of high yielding dairy cattle, the growth in the number of local cross bred is significant and imported cattle are rather expensive and are not well adopted with the environment.

\section{Ways to increase the productivity and reduce cost of production}

Much greater emphasis must be placed on developing the knowledge and skills to introduce and manage high quality improved feeding system successfully. This would involve more use of improved quality grasses, legumes and treated agricultural byproducts which could result in an reduction of the need for concentrates. It is recognized that animal performance and especially milk production is much more dependent on the quantity and quality of feed eaten rather than on the genetic make up of the animal. Furthermore, the management systems of the animals should be improved in order to increase the conception rate and reduce health problems.

Application of feeding standards by farmers require information on the nutritive value of available feed ingredients, the amount of feed intake and the requirement of the animals. But the farmers are mostly illiterate and the information are not available to them. In this circumstance the developed technology in dairy production of neighbouring countries with similar environmental condition and animal body size and productivity can be applied. Research collaboration and the exchange of information among the countries sharing similar constraints will enhance the development of dairy production. 


\section{Available feeding standards}

Different countries have evolved their own standards based on experiments conducted with farm animals in the agro-climatic and economic condition prevailing in the country (De Boer and Bickel, 1988). In U.K. as per recommendation of technical committee set up by Agricultural Research Council (ARC) has been publishing updates of these requirements (Rook, 1991). In the USA the committee on Animal Nutrition under the auspices of the National Academy of Sciences-National Research Council (NRC) and the US department of Agriculture has been recommended the Nutrient Allowances for dairy cattle. The Committee considered nutrient requirements of all symptoms of nutritional deficiency. The latest requirements which are now designed to meet the needs of the animals that have higher than average requirements for essential nutrients. In Europe, there are feeding standards for their own dairy cattle, similarly there are standards for Scandinavian countries.

But in Asia there are not many standards or requirements which could be compared with either NRC or ARC for different nutrients. Recently, tables with nutrient values and requirements are published in Sri Lanka, Malaysia and Indonesia (Ibrahim, 1988; Devendra, 1979 and Hartadi et al., 19980). In India, during the last four decades, serious efforts have been made to develop feeding standards and initially a feeding systems was suggested by Sen (1956) by taking mid-range values given by Morrison (1956). These data was revised by Sen et al. (1978), Ranjhan (1990) and the ME system was introduced together with TDN. The publication of Kearl (1982) on nutrient requirement for the developing countries was based on Indian work.

\section{Nutrient requirements and feeding of dairy calves}

The nutrient requirement of growing calves is usually divided into two phases: preruminant or pre-weaned growth phase which is before the full development of rumen and the second phase is post-ruminant or post-weaned phase which is after the establishment of microbial population in the rumen. Feeding calves during pre-ruminant period is vital as because they can not digest low quality animal feedstuffs and that is why they are to feed on cows milk which is used by farmers for their own consumption and/or for selling to earn money. The pre-ruminant period of a calf is about 2 months from birth during this period sufficient amount of cows milk is to be supplied in order to make them healthy and good growing. Just, within four hour after birth calves are to be fed colostrums at the rate of approximately one-tenth of the live weight and should be continued up to 4 days. Colostrums contains high amount of protein, vitamin A and antibody for growth and development of immunity of the body. The new born calves may start eating dry food particularly calf starter and hay from the $2^{\text {nd }}$ or $3^{\text {rd }}$ week of age in small quantities. The consumption of dry feed will gradually increase if the quantity of milk supplied to calves is gradually reduced. Feeding practices of calves vary greatly. The duration of milk feeding of a calf may be continued up 6 weeks of age of calves, one can withdraw milk feeding as early as 45 days after birth. Straw and coarse fibrous feeds may be supplied at 13 weeks of age. After 60 days ( 2 months) of calves age it is necessary to supply with good quality grasses and hays to accustomed the calves with roughages. Table 2 shows the nutrient requirements of calves at its pre-ruminant phase. 
Bang. J. Anim. Sci. 2009, 38(1\&2)

Table 2. Daily nutrient requirements of pre-ruminant calves (Ranjhan, 1990)

\begin{tabular}{|l|c|c|c|c|c|c|c|c|c|}
\hline \multicolumn{1}{|c|}{ Age } & LW (kg) & ADG $\mathbf{( g )}$ & DCP $\mathbf{( g )}$ & $\begin{array}{c}\text { TDN } \\
(\mathbf{k g})\end{array}$ & $\begin{array}{c}\text { ME } \\
\text { (Mcal) }\end{array}$ & Ca (g) & P (g) & $\begin{array}{c}\text { Vit.-A (100 } \\
\text { IU) }\end{array}$ & $\begin{array}{c}\text { Vit.-D } \\
\text { (IU) }\end{array}$ \\
\hline 1-15 days & 25 & 200 & 80 & 0.4 & 1.5 & 2.5 & 1.5 & 1.5 & 200 \\
16-30 days & 30 & 300 & 90 & 0.5 & 1.7 & 3.0 & 2.0 & 1.5 & 200 \\
31-60 days & 40 & 300 & 125 & 0.8 & 2.4 & 3.5 & 2.5 & 1.7 & 250 \\
61-90 days & 50 & 350 & 150 & 1.0 & 3.6 & 4.0 & 3.0 & 2.0 & 360 \\
\hline
\end{tabular}

\section{Feeding of dairy calves}

There is no more important in the care and management of a dairy herd than rearing of calves. Well grown, vigorous animals are usually those that have had excellent care from birth. Under nourished, stunted calves although not always be grown out into large animals by careful feeding but calves that are thrifty, vigorous and large when 6 months of age are much more resistant to disease and have a much more opportunity to develop into an useful cow.

The nutrient requirement in the case of growing calves can be divided into:

i) Pre-ruminant growth period (Birth to 2 months of age)

ii) Post-ruminant growth period

The reticulo-rumen has an inherent capacity of 2 Lit. at birth. Introducing roughage and concentrate in the diet of calves at an early age will help in early establishment of microbial population and development of rumen, resulting in utilization of coarse fodders and starchy foods into a form of energy available to young calves, synthesize B vitamins and protein from simple nitrogenous compounds. Addition of protein of high biological value will advantageous in the diet of calves until the rumen function will be at optimum. Care must be taken to supply required amount of $\mathrm{Ca}, \mathrm{P}, \mathrm{Na}, \mathrm{Mg}, \mathrm{K}, \mathrm{S}, \mathrm{Fe}, \mathrm{Mn}, \mathrm{Cu}, \& \mathrm{Zn}$ in the diet.

A major portion of the requirements of energy and protein for the pre-ruminant calves are met by whole and skim milk. Calves start eating dry foods like calf starter and hay from the second week after birth.

\section{Methods of feeding}

Each calf should be given the colostrum of its dam within 8-12 hours after birth and subsequently twice daily for 3 days.

\section{Importance of colostrum}

i. The protein of colostrum consists of much higher proportion of globulin than that of normal milk. The globulin are the sources of antibodies.

ii. The protein content of colostrum is 3-5 times higher than normal milk. It is also rich in $\mathrm{Cu}, \mathrm{Fe}, \mathrm{Mg} \& \mathrm{Mn}$.

iii. It contains 5-15 times more vit. A than normal milk.

iv. It is rich in other vitamins also.

v. It acts as laxative. 


\section{Feeding whole milk}

The basis for calculation of milk allowances is that for the first 3 weeks it is $1 / 10^{\text {th }}$ of BW, for the next 2 weeks it is $1 / 15^{\text {th }}$ and than $1 / 20^{\text {th }}$ of the BW. Divide the milk allowances into equal fractions and supply 3 times.

\section{Substituting whole milk by skim milk}

Substitution of skim milk for whole milk may begin when calves are about five weeks of age. This substitution must be a gradual one.

\section{Feeding dried skim milk, whey or buttermilk}

In case these products are available at a reasonable rate, they can be fed to calves. The dried products are mixed with water at the rate of 1:9. It must be fed after warming at $100^{\circ} \mathrm{F}$.

\section{Feeding milk replacements}

Milk replacements are generally served to calves when they attain the age of 1 week. The amount is gradually increased with a decrease of whole milk.

\section{Feeding calf starters}

Calf starter is a mixture consisting of ground grains, protein feeds and minerals. The mixture is reinforced with vitamins and antibiotics. An ideal calf starter contains about $20-23 \%$ DCP and $70 \%$ TDN.

\section{Feeding grain mixtures}

Better growth and greater resistance to calf results from consumption of both grain and milk than only milk. At the age of 7-15 days the feeding grain mixtures may be started. At the age of 2-3 months supply $1 \mathrm{~kg}$ and $1.5-2 \mathrm{~kg}$ at the age of 6 months. Excessive rich grain mixtures is not desirable.

\section{Feeding silage}

Fed 1-1.5 kg good quality silage to calves at the age of 3-4 months and then increase the amount by $0.5 \mathrm{~kg}$ for each month of the calves age.

\section{Pasturing calves}

A separate pasture for calves is needed to prevent injury.

Calves may be allowed to pasture at the age of 1 year.

\section{Supplying antibiotics}

Aureomycin and terramycin increases the growth rate of heifers without any adverse effect upon reproduction or milk production. The rate is 80 milligrams per calf per day from 4-116 days of age. It helps to increased gain from 10-30\%, Improved appetite, Reduced calf scours, Produced smoother hair coats. 


\section{Feeding of dairy calves from 3 months to maturity}

Straws and concentrate mixture normally fed to young stock is difficult to satisfy the NRC standards especially energy. Studies on growth have shown that when straw constitutes the basic roughage, a rate of growth $0.8 \mathrm{~kg}$ can be obtained by feeding nearly $2.5 \mathrm{~kg}$ concentrate mixture with $2.5 \mathrm{~kg}$ green grass and $2 \mathrm{~kg}$ straw in cattle \& buffalo calves of $200 \mathrm{~kg} \mathrm{BW}$. On this ration bull calves and heifers show maturity at about 2 years but cross bred at 18 months. On the other hand where 50 to $60 \%$ of DM is substituted by concentrates, rate of growth is increased very much. Calves of $180 \mathrm{~kg} \mathrm{BW}$ can easily consume $4.8 \mathrm{~kg}$ DM.

\section{Nutrient requirement for dairy animals}

The four standards NRC (1988), ARC (1980), Sen et al. (1978) and Ranjhan (1990) have been discussed in this paper. The NRC and ARC standards were formulated for animals raised under temperate conditions with feedstuffs of high quality. The standards of Sen et al. and Ranjhan are based on poor quality forages under tropical conditions:

\section{Dry matter intake (DMI)}

The willingness or ability of an animal to consume a particular feed is the key factor in determining the amount of nutrient available to the animals. The feed intake is influenced by many factors, including feed characteristics, animal species, physiological state, ambient temperature, management practices the way of feed presentation and also on milk production of the animal. Several workers have tried to predict intake of animals either empirically or from biological parameters (Forbs, 1986; Ketelaays and Tolkamp, 1991; NRC, 1987). These predictions are generally based on intakes measured under controlled experimental conditions rather on farm feed intake. It is evident from Table 2 that dry matter intake decrease linearly with advancement of body weight of dairy animals. NRC (1988) uses the term "requirements" to describe estimates of dry matter intake. The estimates of DMI for dairy animals weighing between 100-600 $\mathrm{kg}$ have been given in the Table 2, where DMI were similar for body weigh between 200 and $300 \mathrm{~kg}$ and also for 350 and $400 \mathrm{~kg}$ indicating a constant feed intake at certain levels of body weight (Table 3).

\section{Energy requirements}

To determine the energy requirement of dairy animals it has been customary to partition the requirements into that the required for maintenance, on the one hand, and that for production, on the other. Thus factors associated with differences in the body-weight, breed and sex can be considered under the former while the quantity, quality and nature of deposited materials can considered under the later. Since both the maintenance requirement and the extent of production influence the animal's thermal losses, it is necessary that these losses be considered in the calculation of the requirements and the results expressed in terms of metabolizable energy (ME). The ME system was developed in the U.K. by Blaxter and adopted by the ARC in 1965. In the USA, feed rationing for ruminants is also based on energy but the standards are expressed as Net Energy (NE) (NRC, 1984, 1987, 1988). In Asian countries the use of TDN has been well practiced since these values are available for a wider range of feed. Measurement of 
ME and NE is more difficult (Ranjhan, 1993) but it can be predicted form TDN (1 Kg $\mathrm{TDN}=4.409 \mathrm{Mcal} \mathrm{DE}), \mathrm{ME}=08^{*} \mathrm{DE} ;$ Net energy for lactation $\left(\mathrm{LE}_{\mathrm{L}}\right)(\mathrm{Mcal} / \mathrm{lb} \mathrm{DM})=$ (TDN\% of DM*of 0.1114) - 0.054(James et al., 1990).

Table 3. Daily dry matter requirement of dairy cattle

\begin{tabular}{|c|c|c|c|c|c|c|}
\hline $\begin{array}{c}\text { Live weight } \\
\text { (kg) }\end{array}$ & $\begin{array}{c}\text { Wt. gain } \\
\text { (g/day) }\end{array}$ & $\begin{array}{c}\text { NRC (1989) } \\
\text { (Kg/daylani } \\
\text { mal) }\end{array}$ & $\begin{array}{c}\text { ARC (1980) } \\
\text { (Kg/dayl } \\
\text { animal) }\end{array}$ & $\begin{array}{c}\text { ICAR (1985) } \\
\text { (Kg/daylani } \\
\text { mal) }\end{array}$ & $\begin{array}{c}\text { Ranjhan } \\
\text { (1990) } \\
\text { (Kg/daylani } \\
\text { mal) }\end{array}$ & $\begin{array}{c}\text { Dry matter } \\
\text { intake (DMI) } \\
\text { (\% of live } \\
\text { weight) }\end{array}$ \\
\hline 100 & 400 & 2.41 & 2.8 & 2.75 & 2.6 & 3.5 \\
150 & 400 & 3.31 & - & 3.90 & 3.8 & 3.0 \\
200 & 500 & 4.24 & 4.3 & 5.02 & 5.0 & 2.5 \\
250 & 500 & 4.99 & - & 5.97 & 6.2 & 2.5 \\
300 & 500 & 5.89 & 5.6 & - & 7.0 & 2.5 \\
350 & 500 & 6.86 & - & - & 7.0 & 2.0 \\
400 & 500 & 7.90 & 6.8 & - & 8.0 & 2.0 \\
500 & 500 & 10.28 & 7.9 & - & - & - \\
600 & 500 & 13.25 & 8.9 & - & - & - \\
\hline
\end{tabular}

Energy requirements of dairy animals by different systems have been showing in Table 4. The energy requirement proposed by NRC (1989), ARC (1980) and Ranjhan (1980) are comparable with each other with a difference of $8-10 \%$. The requirement suggested by Ranjhan is little bit higher than NRC which indicates the higher energy requirement of Zebu cattle.

Table 4. Daily energy requirement of dairy cattle with weight gain of $500 \mathrm{~g}$

\begin{tabular}{|c|c|c|c|c|c|c|}
\hline \multirow{2}{*}{$\begin{array}{c}\text { Live weight } \\
\mathbf{( k g )}\end{array}$} & \multicolumn{2}{|c|}{ NRC (1989) } & \multicolumn{2}{c|}{ ARC (1980) } & \multicolumn{2}{c|}{ Ranjhan (1990) } \\
\cline { 2 - 7 } & ME (Mcal) & TDN (kg) & ME (Mcal/d) & TDN (kg) & ME (Mcal) & TDN (kg) \\
\hline 100 & 6.54 & 1.72 & 6.9 & 1.9 & 6.6 & 1.9 \\
150 & 8.55 & 2.25 & - & 2.6 & 9.4 & 2.6 \\
200 & 8.55 & 2.25 & 10.7 & 3.0 & 10.8 & 3.0 \\
250 & 12.31 & 3.27 & - & - & - & - \\
300 & 14.15 & 3.77 & 14.0 & 4.0 & 14.4 & 4.0 \\
350 & 16.01 & 4.29 & - & - & - & - \\
400 & 17.91 & 4.82 & 17.0 & 5.0 & 18.1 & 5.0 \\
500 & 21.93 & 5.98 & 20.0 & - & 22.1 & 6.0 \\
600 & 26.50 & 7.29 & 22.4 & - & - & - \\
\hline
\end{tabular}

\section{Protein requirements}

The protein represents a very important group of nutrients in the feed which are used for a variety of purposes within the body. Their most important function is the supply of 
amino acids for the production of body protein and for the synthesis of non-essential amino acids. Thus the efficiency with which dietary protein is utilized will depend upon its amino acid composition. For efficient utilization, the feed must supply the correct quality of the essential amino acids and sufficient of the non-essential amino acids to meet the metabolic demands of the dairy animals.

The most used method in Bangladesh to express the protein requirements of the dairy animals is the Crude Protein (CP) and Digestible Crude Protein (DCP). The DCP method gives too much weight to non-protein nitrogen (NPN) relative to intact protein. ARC (1965) proposed that protein requirement be expressed as available protein i.e. the amount of crude protein of defined biological value that would have to be absorbed from the digestive tract to meet the calculated requirements.

A new approach in calculating protein requirements as UDP and RDP was proposed by Nolon and Leng (1972). On the other hand, in the USA Burrough et al. (1975) proposed the metabolizable protein system. Protein requirements are compared in Table 4, 5 and 6 , where a small difference was observed among the recommendations with a 5-10\% higher values for Ranjhan (1990).

Table 5. Daily protein requirement of dairy cattle with an average body wt. gain of $500 \mathrm{~g}$

\begin{tabular}{|c|c|c|c|c|c|}
\hline \multirow{2}{*}{$\begin{array}{c}\text { Live weight } \\
\mathbf{( k g )}\end{array}$} & NRC (1989) & Sen et al. (1978) & ICAR (1985) & \multicolumn{2}{|c|}{ Ranjhan (1990) } \\
\cline { 2 - 6 } & DCP (g) & DCP (g) & DCP (g) & DCP (g) & CP (g) \\
\hline 100 & 392 & 280 & 328 & 280 & 400 \\
150 & 525 & 350 & 442 & 350 & 500 \\
200 & 573 & 400 & 556 & 400 & 555 \\
250 & 598 & 470 & - & 470 & 671 \\
300 & 707 & - & - & - & - \\
350 & 823 & 480 & - & 480 & 700 \\
400 & 947 & - & - & 450 & - \\
500 & 1083 & - & - & - & - \\
600 & 1590 & - & - & - & - \\
\hline
\end{tabular}

Table 6. Daily energy and protein requirement for body maintenance

\begin{tabular}{|c|c|c|c|c|c|c|c|c|}
\hline \multirow{2}{*}{$\begin{array}{c}\text { Live } \\
\text { weight } \\
\mathbf{( k g )}\end{array}$} & \multicolumn{3}{|c|}{ NRC (1989) } & \multicolumn{2}{c|}{ Sen et al. (1978) and Ranjhan (1990) } & \multicolumn{2}{c|}{ ICAR (1985) } \\
\cline { 2 - 9 } & CP (g) & TDN (kg) & $\begin{array}{c}\text { ME } \\
\text { (Mcal) }\end{array}$ & DCP (g) & TDN (kg) & ME (Mcal) & DCP (g) & TDN (kg) \\
\hline 250 & - & - & - & 168 & 2.02 & 7.27 & 140 & 2.2 \\
300 & - & - & - & 197 & 2.36 & 8.50 & 1.68 & 2.65 \\
350 & - & - & - & 227 & 2.70 & 9.72 & 195 & 3.10 \\
400 & 318 & 3.13 & 12.01 & 254 & 3.03 & 10.91 & 223 & 3.55 \\
500 & 364 & 3.70 & 14.20 & 296 & 3.69 & 13.28 & 278 & 4.45 \\
550 & 386 & 3.97 & 15.25 & 336 & 3.71 & 13.36 & 310 & 4.90 \\
\hline
\end{tabular}




\section{Guidelines for establishing feeding system}

Feeding system can be based on farmer's experience, or on feeding trials in research centre. In order to develop feeding system it is necessary to relate information on the nutritional characteristics of feed resources with requirements for nutrient according to the purpose and rate of productivity of the animal in question. In the industrialized countries, this information has been incorporated in tables of "feeding standards" which interpret chemical analysis of feed resources in term of their capacity to supply the nutrients. These standards are steadily becoming more sophisticated with the aim of improving their effectiveness in predicting rate of performance of intensively-fed livestock to derive least cost formulation. But the relevance of feeding standard for developing countries has been questioned from the socio-economic (Jackson, 1980) and technical (Graham, 1983 and Preston, 1983) viewpoints. It has been apparent for many years that feeding standards base on assigned nutritive value (i.e. energy) are misleading when unconventional feed resources are used in formulation (Gaya et al., 1988) and Leng and Preston (1976) because, this often led to the rejection of many feed resources which were too low in DE energy to supply the energy needed for production of the animal.

In Bangladesh most forages consumed by livestock are relatively low in digestibility (40$50 \%$ ). The metabolizable energy in the dry matter, thus ranges from $4.8-7.5 \mathrm{MJ} / \mathrm{kg} \mathrm{DM}$ (Khan, 2000). According to feeding standards, a metabolizable energy content in a feed of 7.5 will support a gain of approximately $2 \mathrm{~g} \mathrm{MJ}$ of ME intake in cattle. As a consequence of $4.8 \mathrm{MJ} / \mathrm{kg} \mathrm{DM}$, animal are usually in negative energy balance (ARC, 1980 and Webster, 1989). On the other hand, supplying urea with low quality forages growth rate of animal can be attained up to $18 \mathrm{~g} / \mathrm{MJ}$ of ME intake (Saadullah, 1984).

\section{Relevance of feeding standards in practical feeding of dairy animals}

Smallholder farmers are fed to their dairy animals straws/stovers and other crop residues along with little bit of grazing or cut and carry grasses. Lactating animals sometimes receive a concentrate feeds containing only in the milk shed areas (Bathan) recently adopt the use of balanced concentrate mixtures for feeding milking cows. However, they follow traditional feeding systems and do not know the scientific nutrient requirements developed by NRC, ARC, ICAR or others. That is to say, farmers do not use book valued and terms like ME, TDN, or DCP but they practice the standards on they have learned by their own experience. (Rangnekar, 1993; Jackson, 1980 and Shciere and de Wit, 1993). Farmers are bound to accept low production of their animals for economic reasons due to unavailability of good forage and high price of concentrates. In the foreseeable future it is not possible to feed the cattle as per nutrient requirements. Standards or requirements can however be useful if they are conceived as a set of rules, based on farm and laboratory experience and with feedstuffs within the reach of farmers and moreover economically feasible feeding systems. In that sense, it is the application of feeding system rather feeding standards.

The major portion of non-descript cows yield on an average 1.5 liters of milk per day and such animal need little or no concentrates with the basal roughage is of reasonable quantity and quality (treated straw). The cross bred cows yielding 5-8 litres of milk 
require better feeding (supplementation of concentrates) depending on their body weight. But such feed is not available at economically attractive prices. The proper use of feeding system will help to determine the maximum productivity of cows economically. Treated straw and some green grass feed with salt and mineral mixture are sufficient for low milk yielding animals and for cross bred animals for body maintenance.

\section{Practical applicability}

Bangladesh farmers adopt traditional methods in selection, preparation and mixture of feed in a wide array of feeding practices. Formulations of ration for these condition is seldom done, but to get maximum production there is no alternative of ration formulation. This involves complex calculation which take into consideration a large number of variables. The primary information needed in formulation of a ration are:

- nutrient requirement of animals for maintenance, growth, production etc.

- nutritive value and other characteristics of the feeds

- availability of the feedstuffs vis-à-vis the animal performance.

But, all the above required information are not available to the farmers, at the same time farmers are not educated enough to acquire the knowledge of feed formulation.

For these technical reasons, and also because of differing socio-economic circumstances, it is almost necessary to develop a feeding system for developing countries to match livestock production system with the available resources mainly crop by products (Preston and Leng, 1986). The main constraints to milk production or diets based on crop residues and agro-industrial by products appear to be the availability of glucogenic components to provide the glucose for lactose synthesis and for oxidation to provide the NADP (Nicotinamide adenine di-neucleotide phosphate) for synthesis of fatty acids.

There is good evidence that in large ruminants about $50 \%$ of the fatty acids of milk arise from dietary fat. A dietary source of fat can thus reduce considerably any imbalance caused by relative deficiency of glucogenic energy and amino acids in the end products of rumen digestion. Supplementation of lactating animals, particularly or diet based or traditional pasture, crop residues and agro-industrial by products should aim to correct the imbalances of nutrients for milk production. By pass protein usually promotes milk production (Orskov et al., 1977). By pass protein because of its effects on feed intake almost always stimulate milk production and depending on the imbalance in nutrients (fermentation pattern) may cause animals to mobilize body reserves. This may be prevented by the use of high-fat, high-protein meals that supply both protein and low chain fatty acids for digestion post-ruminally. Considering the above facts and to ensure maximum utilization of available feed resources, the approximate feeding system should be based on supplementation technique following the principles:

a) Basal carbohydrate rich resource: The first step is to select the basal carbohydrate resources according to availability, potential fermentability and price. Supplementary 
nutrients should then be provided in accordance with their relative priorities and costs (e.g. pastures, crop residues, cut forages and agro-industrial by products (molasses, citrus pulps, waste pineapples, jack fruits, bananas and other fruit residues).

b) Fermentable nitrogen and mineral: The main supplements to be considered should be a source of fermentable nitrogen (urea) with a combination of some minerals to ensure the level of rumen ammonia to above $150 \mathrm{mg} /$ litre of rumen fluid.

c) Supply of available protein: A supply of highly digestible forage (young grass, mainly legume at a rate of $10-15 \%$ of the diet given best results (Silva and Orskov, 1985) should be ensured.

d) Substantial proportion of bypass protein: Provide a source of by- pass protein (oil seed meal, fish meal, cereal bran, lignin containing legume) at a level of $10 \%$ of the total DM requirements.

\section{Available feed resources and their utilization}

Feed resources available in the country for dairy animals are dry roughage (straw, stover, begasse and haulms from legume crops), green grass (non-cultivated indigenous grass, crop field weeds, road \& embankment side grass, water-hyacinth, cultivated fodder, legume, non-legume and perennial grasses from fallow lands and forests), vegetables and fruit by-products (Jack fruit, pineapple, banana, mango, cabbage and other kitchen waste), shrubs and fodder tree leaves etc. (Table 7). Among concentrate supplements, agro-industrial by products (rice bran, wheat bran, oil cakes, and molasses) marine and animal by products (fishmeal, shrimp waste, blood meal, bone meal) are the commonly available feed ingredients. But in practical, feeding of dairy animals are mainly based on crop residues and by products of cereals, oil seeds and pulses.

Table 7. Nutrients requirements for milk production $(\mathrm{kg})$

\begin{tabular}{|c|c|c|c|c|c|c|c|c|}
\hline \multirow{2}{*}{$\begin{array}{c}\text { Butter } \\
\text { fat (\%) }\end{array}$} & \multicolumn{3}{|c|}{ NRC (1989) } & \multicolumn{3}{c|}{ Sen et al. (1978) } & \multicolumn{2}{c|}{ ICAR (1985) } \\
\cline { 2 - 8 } & CP (g) & TDN (kg) & ME (Mcal) & DCP (g) & TDN (kg) & ME (Mcal) & DCP (g) & TDN (kg) \\
\hline 3.0 & 78 & 280 & 1.07 & 40 & 269 & 0.97 & 48 & 275 \\
3.5 & 84 & 301 & 1.15 & - & - & - & 51 & 300 \\
4.0 & 90 & 322 & 1.24 & 45 & 316 & 1.14 & 55 & 325 \\
4.5 & 96 & 343 & 1.32 & - & - & - & 58 & 350 \\
5.0 & 101 & 364 & 1.40 & 51 & 363 & 1.31 & 62 & 375 \\
5.5 & 107 & 385 & 1.48 & - & - & - & 65 & 400 \\
6.0 & - & - & - & 57 & 411 & 1.48 & 68 & 425 \\
7.0 & - & - & - & 63 & 458 & 1.65 & 75 & 475 \\
8.0 & - & - & - & 69 & 539 & 1.82 & 79 & 500 \\
\hline
\end{tabular}


The natural green grasses are available intensively during rainy season and in winter some legumes are grown sporadically in some areas of the country. The remaining six months availability of green grass is very limited and during this time rice straw alone contributes $87 \%$ of roughage portion of the dairy feed. Considering the availability of feedstuff throughout the year feeding systems for dairy animals should be based on crop residues, sugarcane tops and supplementation of legumes along with rice bran or concentrate feed. Forage production from crop residues of rice straw, wheat straw, soybean straw and other residues from oil cake producing plants can contribute substantially to the process of dairy animal rearing.

Promma et al. (1985a) demonstrated that dairy cows fed with urea-treated rice straw has similar milk yield that of cows feed with fresh grass, and intake of the cows fed ureatreated rice had a higher milk fat content and net income as compared with the milk produced by cows fed untreated straw and leucern leaf. Several methods to treat the straw to increase digestibility are available. But, at the present time, the only method recommended for practical application in rural Bangladesh involves ammoniation through wet ensiling of the material with urea. For this purpose, straw is to be mixed with an equal weight of water containing 4-5\% urea. This mixing may be done in pot, or in a container such as basket lined with mud or even on the floor. It is advantageous to add a meal containing urease (e.g. soybean meal, legume beans, middling soil or even livestock excreta (khan et al 1990). After mixing, the urea treated straw is to be sealed with a plastic bag and left for a period between 7 to 28 days. The higher the ambient temperature, the shorter the time needed for digestibility to be increased (Jayasuriya, 1984). Evidence for the reaction taking place is a change in color of the fibrous material usually to a bright yellow. Treated straw can be fed immediately following ammoniation. It must not be sun-dried as this result in a loss of gaseous ammonia.

Nowadays maize of different varieties are widely cultivated in different areas of the country, after harvesting grain the remaining stalks and leaves can fed after processing. Similarly after harvesting pods from soybean and ground nut, the haulms could be used successfully as dairy animal feed.

The harvesting period of sugarcane in the country is between November and April, when there is a acute shortage of green grass, the top could be used as valuable alternatives feed resources for dairy animals during this period. Nutritive value of chopped sugarcane tops was found to contain more ME and digestible nutrients than other dry roughage (Polser et al., 1996).

Regarding concentrate, rice bran is available year-round and the price of the bran is far less than the other concentrates with almost similar nutrient content. During the dry season, when animals are fed only crop residues, farmers have to feed more concentrate to the dairy animals resulted increased production cost. To minimize cost of milk production rice bran can be mixed well with oil cake at a ratio of 3:1. 


\section{Feeding guideline for small holder dairy}

Nutrient requirement vary with the stage of lactation and gestation. To attain optimum productivity, five phases of dairy cow feeding should be followed:

- Early lactation- 0 to 70 days (peak milk production) after calving

- Peak DM intake-70 to 140 days (declining milk production) post partum

- Mid and late lactation-140 to 205 days (declining milk production) post partum.

- Dry period- 60 to 14 days before the next lactation.

- Transition or close-up period-14 days before parturition.

Phase I: Milk production increases rapidly during this period, peaking at 6 to 8 weeks after calving. Feed intake does not pace with nutrient needs for milk production especially for energy and body tissue will be mobilized to meet energy requirement needs for milk production. Increasing grain about $500 \mathrm{~g} / \mathrm{day}$ after calving will increase nutrient intake. Fiber level in the total ration should not be less than $18 \%$ ADF, and $28 \%$ NDF.

Protein is critical nutrient during early lactation. Meeting CP requirements during this period helps to stimulate feed intake and permits efficient use of mobilized body tissue for milk production. Rations should contain $18 \% \mathrm{CP}$ to meet the requirements during this period. A good guideline is to feed $500 \mathrm{~g}$ soybean meal or equivalent commercial supplements per 5 Lit of milk.

Phase II: Cows should be maintained at peak production as long as possible. BW of the animals must be strictly maintained.

Phase III: Milk Production is declining, the cow is pregnant which requirement can easily be met. Grain feeding should be at least to meet milk production requirements

Phase IV: The dry period is a critical phase of the lactation cycle. A good sound dry cow program can increase milk yield during the following lactation and minimized metabolic problems at or immediately after calving.

Phase V: The transition or close-up dry cow feeding program is critical. Some grains, if not previously fed should be fed starting two weeks before freshening. Introduction of grain is necessary to begin changing the rumen bacteria production.

\section{Feedstuffs}

Legumes and grasses are major source of forage for dairy animals. These forages are excellent sources of protein, carotene, $\mathrm{Ca}$ and other minerals. High quality forages can make up as much as $2 / 3$ of the ration's DM. High quality forages feed in balanced ration will supply much of the protein and energy needs for the milk production. 
Bang. J. Anim. Sci. 2009, 38(1\&2)

The main nutrient contribution of grains and by product feed is energy. As much as $30 \%$ of the whole grain will pass through cows intact if the grain is not processed before feeding. Coarse-textured, processed grain enhances palatability and intake.

\section{Suggested ration for different intensity of milk production}

The objective in formulating ration is to provide animals with a consumable quantity of feedstuffs that will supply all required nutrients in adequate or greater amounts and do so in a cost effective way. The following (Table 8) rations based on rice straw as basal feed can be practiced by smallholder farmers most easily and economically. Table 9 shows the complete rice straw-based dairy animal ration for various production intensity

Thumbs rule for lactating cows:

a) DMI will depend on the body weight of the animal. The more the body weight, the more the less the unit of dry matter intake per unit body weight and vice-versa. Generally DMI of dairy animals vary between 2 to $3.0 \mathrm{~kg}$ per $\mathrm{kg}$ body weight.

b) Forage DM minimum $40 \%$ of total DMI or approximately $1.5 \%$ of BW.

c) Maximum grain DMI is $80 \%$ or $2 \%$ of BW for 5 to 30 Lit milk/day. Feed grain $500 \mathrm{~g}$ for 1.5 Lit lb of milk.

d) Protein $17-19 \%$ in early lactation ration. Limit urea to $200 \mathrm{~g} /$ day.

e) Maximum total fat in ration is $7 \%$ of the DM and not more than $2 \%$ of any one of animal or plat source.

f) A Ca-P mineral source should be included in the grain mixture at 1 to 2 per cent or 1 oz per 5 Lit of milk.

g) Supplemented vitamin A, D; and E and trance minerals to meet the requirement.

h) Salt should be included in the grain mixture at $1 \%$ level.

Table 8. Type of available fodder and their sources

\begin{tabular}{|c|c|}
\hline Origin & Type \\
\hline \multirow{6}{*}{ Agricultural land } & Cutivated fooder \\
\hline & Crop residues \\
\hline & By-products from processing of harvested materials (haulms) \\
\hline & Weeds \\
\hline & Grass and weeds from fallow land \\
\hline & Natural vegetation (grass, shrubs and weeds \\
\hline \multirow{4}{*}{ Common land } & Forest \\
\hline & Water plants \\
\hline & Grass \\
\hline & Tree leaves \\
\hline \multirow{2}{*}{ Homestead } & Vegetable, fruits and kitchen waste \\
\hline & Weeds \\
\hline
\end{tabular}


Table 9. Complete rice straw-based dairy animal ration for various production intensity

\begin{tabular}{|c|c|c|c|c|c|c|}
\hline \multirow[b]{2}{*}{$\begin{array}{l}\text { Ingredients } \\
(\mathrm{Kg} / 100 \mathrm{Kg})\end{array}$} & \multicolumn{4}{|c|}{ Milk yield (Lit.) } & \multirow[b]{2}{*}{ Heifer } & \multirow[b]{2}{*}{$\begin{array}{l}\text { Pregnant } \\
\text { cows }\end{array}$} \\
\hline & $\begin{array}{c}\text { Low } \\
\text { production } \\
\text { intensity } \\
(1-3)\end{array}$ & $\begin{array}{c}\text { Medium } \\
\text { production } \\
\text { intensity } \\
(4-7)\end{array}$ & $\begin{array}{c}\text { Intensive } \\
\text { production } \\
(8-11)\end{array}$ & $\begin{array}{c}\text { High } \\
\text { yielding } \\
(12-16)\end{array}$ & & \\
\hline Rice straw (treated*) & 10 & 8 & 6 & 6 & 6 & 7 \\
\hline Green grass/silage & 8 & 12 & 17 & 20 & 10 & 14 \\
\hline Concentrate mixture & $1.0-2.0$ & 3.0 & 4.5 & 6.5 & $1.5-2.0$ & $2.5-3.0$ \\
\hline Molasses & 3 & 5 & 5 & 5 & 5 & 5 \\
\hline Mineral mixture• & 0.4 & 0.5 & 0.75 & 0.75 & 0.5 & 0.5 \\
\hline Common salt & 0.2 & 0.2 & 0.30 & 0.30 & 0.2 & 0.3 \\
\hline
\end{tabular}

* Rice straw is to be soaked in molasses water (1:1) where molasses should be well mixed with water before soaking. Soaking may be done for $1^{\mathrm{hr}}$ before feeding.

\begin{tabular}{|lccc|}
\hline \# Concentrate mixture $(\mathrm{g} / 100 \mathrm{~g}):$ & & \multicolumn{2}{c|}{ Mineral mixture $(\mathrm{g} / 100 \mathrm{~g}):$} \\
Rice polish/wheat bran & $35 \%$ & $\mathrm{CaCl}_{2}$ & $28 \mathrm{~g}$ \\
Crushed maize & $30 \%$ & $\mathrm{DCP}$ & $45 \mathrm{~g}$ \\
Oil cake & $20 \%$ & $\mathrm{FeSO}_{4}$ & $5 \mathrm{~g}$ \\
Kheshari / Matikali & $15 \%$ & $\mathrm{Zn}$ & $2 \mathrm{~g}$ \\
& & $\mathrm{MgCo}_{3}$ & $20 \mathrm{~g}$ \\
\hline
\end{tabular}

\section{Conclusions}

Considering the important contribution of small holder dairy production to poverty alleviation and food security. Special action programme should be taken for the urgent development of this sector, of which efficient utilization of available feed resources and a comprehensive breeding programme should be given top most priority. Fodder conservation practices, particularly hay and silage making, should be developed in order to enable a stable feed supply throughout the year. Small holder dairy farmer should be trained up with the concept of feeding interventions and use of concentrate and urea supplementation with rice straw.

\section{Acknowledgement}

The first author acknowledge the receipt of DAAD re-invitation fellowship for three months under which this piece of work was conducted. The logistic support received from the Institute of Animal Sciences, Humboldt University Berlin, Germany are also gratefully acknowledged.

\section{Literature cited}

Agricultural Research Council (ARC), 1980. The Nutrient Requirement of Ruminant Livestock. Commonwealth Agricultural Bureau, London, SWIY 5 AG. 
Bang. J. Anim. Sci. 2009, 38(1\&2)

Agricultural Research Council (ARC), 1990. The Nutrient Requirement of Ruminant Livestock. Commonwealth Agricultural Bureau, London, SWIY 5 AG.

Burrough, W., Nelson, D. K. and Mertens, D. R., 1975. Evaluation of protein nutrition by metabolisable protein and urea fermentation potential. J. Dairy Sci., 58: 611-19.

De Boer, F. and Bickel, H., 1988. Livestock feed resources and feed evaluation in Europe: present situation and future prospects, EAAP publ. 37, Elsevier, Amsterdam.

Devendra, C. 1979. Malaysian feeding stuffs, Malaysian Agricultural Research and Development Institute (MARDI), Serdong, Selangor, Malaysia.

DLS (Directorate of Livestock Services), 2007. Department of Livestock Services - An overview, DLS, Dhaka, Bangladesh.

Forbes, J. M. 1986. The voluntary intake of farm animals, Butterworth Co.

Gaya, H., Hulman, B and Preston, T. R. 1981. Leucaena as a source of protein and roughage for milking cows given high levels of molasses/urea. Tropical Animal Production, 6: 189.

Graham, N. McC. 1983. Feeding standards: an outmoded concept in ruminant ration. Ir. Recent advances in animal nutrition in Australia. Ed. D.J. Farrel and P. Vohra Univ. of new England Publishing Unit, Armidale, pp. 184-91.

Hartadi, H., Reksohadiprodjo, S., Lebosukojo, S., Tillman, A. D., Kearl, L. C, and Harris, L. C. 1980. Tables of feed composition for Indonesia, Fakultas peteruakan, University, Godjah Moda, Yogyakarta, Indonesia, International Feedstuffs Institute, Utah State Univ. UMC 46, Logan, Utah 84322, USA.

Ibrahim, M. N. M. 1988. Feeding tables for ruminants in Sri Lanka. Registrar, Animal Feed Advisory Committee. Veterinary Research Institute. Gannnoruwa, Sri Lanka.

Jackson, M. G. 1980. Who needs feeding standard? Anim. Feed Sci. and Tech. 6: 101-104.

James, J. L., Michael, F., Randy, S., Donald, E. Otterby, W., Terry, H, and Lee, H. K. 1990. Feeding the dairy herd, University of Minnesota, USA, pp. 352.

Jayasuriya, M. C. N. 1984. Potential for the better utilization of crop residues and agro-industrial by-products in animal feeding in the Indian sub-continent. In: Guidelines for research on the better utilization of crop residues and agro-industrial by-products in animal feeding in developing countries. 1. State knowledge Ed. T.R. Preston et al, FAO, Rome.

Kearl, L. C. 1982. Nutrient requirements of ruminants in developing countries. International Feedingstuffs. Instt. Utah Agr. Exp. Stn., Utah State Univ. Logan Utah, USA.

Ketelaars, J. J. M. H., Tolkamp, B. 1991. Towards a new theory of feed intake regulation in ruminantss. 1. Causes of defferences in voluntary feed intake: critique of current views. Livestock Production Science, 30: 269-96.

Leng, R. A. 1981. Factors affecting the utilization of poor quality forage by ruminants particularly under tropical conditions. Nutritional Research Review: 3: 56.

Leng, R. A and Preston, J. R. 1976. Sugarcane for cattle production: present constraints perspectives and research priorities. Tropical Animal Production, 1: 1-22.

Morrison, F. B. 1956. Feeds and feeding. $22^{\text {nd }}$ ed. The Morrison Publishing Co. Clinton, Iowa. USA.

National Dairy Development Board (NDDB), 1989. Annual Report of the National Dairy Development Board, NDDB, Anand, India.

Nolan, J. V. and Leng, R. A. 1972. Dynamic aspects of ammonia and urea metabolism in sheep. Brit, J. of Nutr.. 27: 177-94.

NRC, 1987. Predicting Feed Intake of Food-Producing Animals. National Research council, Washington, DC. 
NRC, 1988. Nutrient Requirement of dairy cattle. $6^{\text {th }}$ Revised Edition. National Academy Press, Washington, DC.

Orskov, E. R., Grubb, J. R. and Kay, R. N. B. 1977. Effect of post-ruminant glucose or protein supplementation on milk yield and composition in Friesian cows in early lactation and negative energy balance. British J. of Nutri. 36: 397-405.

Preston, T. R. and Leng, R. A. 1986. Matching livestock Production with available feed resources. International Livestock Centre, Addis Ababba, Ethiopea.

Preston, T. R. 1983. Feeding standards can be misleading. In: Recent advances in Animal Nutrition in Australia. Ed. D.J. Farrel and P. Vohra. Univ. of new England Publishing Unit, Armidale, pp. 184-91.

Promma, S., Tuibumpec, S., Ratnavenija, A., Vidhyakorn, N., Bromert, R. W. 1985a. The effects of urea-treated rice straw on growth and milk production of crossbred Holstein-Friesian dairy cattle. In: Doyle, P.T. (Ed.), The utilisation of Fibrous Agricultural Residues as Animal Feeds. IDP, Canberra, Australia, pp. 88-93.

Polser, J., Burdin, S., Charoy, J. and Nabos, J. 1996. L'enfouissement des pailles de mil Pennisetum dans les sols sableux dunaires: Son influence sur les rendements et al nutrition minerale du mil; son action sur les caracteristiques chimiques du sol et al. dynamique de l'azote mineral, Agronomie Tropicale 29: 995-1005.

Rangnekar, D. V. 1893. Farmer perceptions of quality and value of feeds, fodder and feeding. Proceeding - Investigations on agricultural waste materials for evolving economic rations for livestock workshop, Poona, India.

Ranjhan, S. K. 1990. Nutritional value of Animal Feeds and Feeding of Animals, ICAR, New Delhi.

Ranjhan, S. K. 1993. Modern approaches to feed evaluation and their application in India. Proceeding - Utilization of Agro-industrial by-products as Livestock Feed, ICAR, New Delhi.

Rook, A. J., 1991. AFRC technical committee on Responses to Nutrients, Report 8, voluntary intake of cattle, Nutr. Abstract and Review. B 61 (11): 815-23.

Saadullah, M. 1984. Studies on Utilization of rice straw by cattle. PhD thesis, Royal Veterinary College, Copenhagen.

Saha, G. C. and Haque, S. A. M. A. 2001. Small-scale processing and marketing in Bangladesh including reference to micro-credit facilities (good market access)-Milk Vita: A case study. ILRI proceedings, Edit. D. Rangnekar and W. Thorpe, Nairobi, Keneya, pp. 327.

Schiere, J. B., De Wit, J. 1993. Feeding standards and tropical feeding systems. Anim. Feed Sci. and Tech. 5: 93-98.

Sen, K. C. 1956. Animal nutrition research in India. Macmillan and Co., Calcutta, India.

Sen, K. C. Ray, S. N. and Ranjhan, S. K. 1978. Nutritive value of Indian Cattle Feeds and Feeding of Animals. ICAR, New Delhi.

Silva, A. and Orskov, E. R. 1985. Effect of unmolasessed sugar beet pulp on the rate of straw degradation in the rumen of sheep given barely straw. Proceeding of Nutrition Society, 44: 50A.

Singh, C. B., Dhaka, J. P. and Sharma, P. K. 1981. Labour absorption and factors influencing levels of employment in crop, dairy and poultry enterprises. Indian J. of Agric. Econ. 36: 4-10.

Webster, A. V. F. 1989. Bioenergetics, bioengineering and growth. Animal Production, 48: 249-69. 